\title{
Water and Salt Distribution in Saline-Sodic Soil as Affected by Peatmoss and Gel-Forming Conditioner
}

\author{
H.A. Abdel Rahman ${ }^{1 *}$ and A.M. Ibrahim ${ }^{2}$
}
${ }^{1}$ Department of Soil and Water Sciences, College of Agriculture, Sultan Qaboos University, P.O. Box 34, Al Khod 123, Sultanate of Oman and ${ }^{2}$ Ministry of Agriculture and Fisheries, Sultanate of Oman

توزيع المباه والأملاح في تربة مليبة قلمية نتيجة لمسنات التربة العضوية والمركبات الههلامية

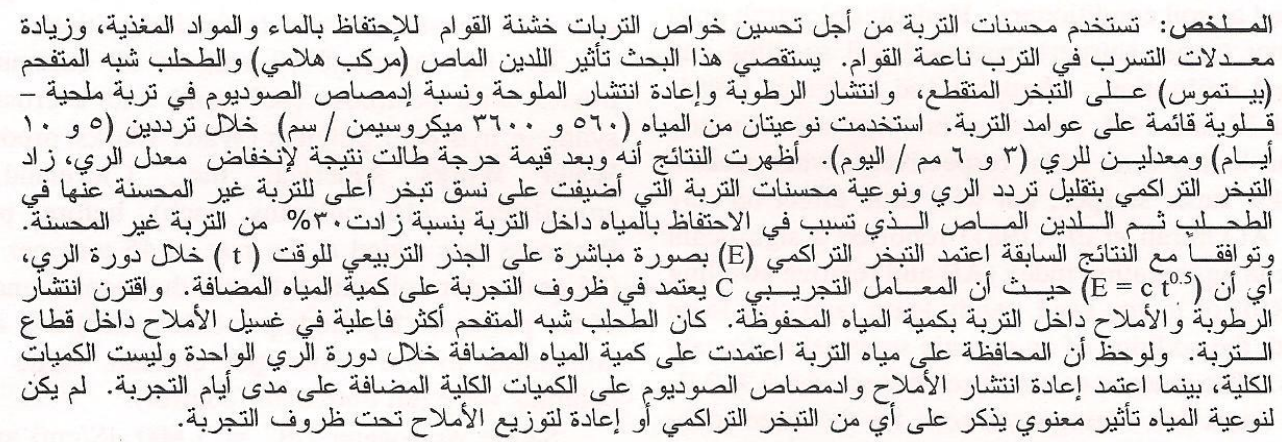

\begin{abstract}
Soil amendments are used to improve the water and nutrient holding capacity of coarse textured soils, and alleviate problems of infiltration and percolation in fine textured soils. The effects of a gel-forming absorbent copolymer and peatmoss as soil amendments, on intermittent evaporation, moisture distribution, and salt redistribution through saline-sodic fine textured soil columns, were investigated. Two water qualities $(3,600$ and $560 \mu \mathrm{S} / \mathrm{cm})$, two intervals of water applications ( 5 and 10 days) and two application rates ( 3 and $6 \mathrm{~mm} \mathrm{~d}^{-1}$ ) were used in the study. The results indicated that after a threshold period which was longer for the lower rate of water application, the cumulative evaporation (E) increased with the decrease in irrigation interval and the type of soil amendments added in the order of control, peatmoss, and the absorbent copolymer. The absorbent copolymer conserved $30 \%$ more water than the untreated soils. In accordance with previous findings, $\mathrm{E}$ was found to be a linear function of the square root of time (i.e., $\mathrm{E}=\mathrm{c} / \mathrm{t}^{0.5}$ ), where $\mathrm{c}$ under the experimental conditions was largely determined by the amount of water applied per irrigation and the type of soil amendment added. Salt and soil water distributions were governed by the amount of water conserved. Within the profile, peatmoss was significantly effective in leaching salts. The quantity of water applied at a time, rather than the cumulative amount, seemed to affect water conservation; whereas the cumulative amount of water applied during the span of study significantly affected EC and SAR re-distributions. The water quality had no significant effect on either evaporation or salt re-distribution under the experimental condition.
\end{abstract}

$\mathrm{R}$ eclamation and improvement of problematic soils have been the subject of numerous investigations. Top dressing with $10 \%$ or less by volume organic matter improved infiltration in poorly structured soils, and internal drainage in fine-textured soils (Carrow et al., 1990). Applications of excessive organic matter $(>20 \%)$ could, however, produce an excessively wet soil by retaining considerable moisture, and the soluble

\footnotetext{
* Corresponding author.
} 


\section{ABDEL RAHMAN AND IBRAHIM}

salts can hinder plant growth or be washed into the ground water (Andrian et al., 1971). Peatmoss, a general name for many types of partially decomposed plant residues, is widely used in the desert sandy soils to improve their water-holding capacities (Abdel Rahman and Abdel Majid, 1993). Synthetic polymers, developed from baby diaper technology that absorb 40500 times their own weight, have been used to alleviate problems of infiltration and water holding capacities of different soils. The addition of water-soluble polymers such as polyacrylamide (PAM), polyvinylalcohol (PVA), or bitumen emulsion to the soil surface tend to increase its aggregation and aggregate stability and reduce evaporation from the soil (Tisdall and Oades, 1982). Johnson (1984) found that PAM reduced evaporation and increased available water in coarse sand, and the effects varied with type of commercial produce used. Tayel and El-Hady (1981) reported an increase in water supply to growing plants with improvement in water use efficiency when polymers were used as soil conditioners. Hydrolyzed starch graft copolymer (super slurper) increased soil swelling and decreased infiltration. Hemyari and Nofziger (1981) reported 18 and $11 \%$ reduction in sorptivity of sandy loam and loamy sand soils, respectively, when treated with $0.4 \%$ super slurper, but with little effect on clay loams. Al-Omran et al. (1987) reported a significant increase in aggregation index (AI) and relative swelling index (RSI) of loamy sand, sandy loam, and clay loam soils with the addition of an organic supergel at the rate of $0.4 \%$. The amount of water conserved was $4.3,3.2$, and 1.5 times that of untreated soils for the three soils, respectively.

Optimal utilization of problematic saline-sodic soils is particularly contingent on proper soil water management. In practice, the desired management should promote salt leaching and estab'ish favorable salt distribution. Intermittent ponding of water was recommended as an efficient method for salt leaching (Oster et al., 1972). Irrigation frequency and water application rates were shown to have significant effects on salt redistribution (Keller and Alfaro, 1966). This study was conducted to investigate the effects of water quality and quantity and intervals of water applications, under relatively long intermittent ponding, on water and salt distribution in saline-sodic soils. The effects of hydrogel conditioner and natural organic amendments were elucidated.

\section{Materials and Methods}

A $150-\mathrm{cm}$ profile was dug in a fine textured salinesodic soil of the Batinah area in the Sultanate of Oman. Field survey methods were'used to delineate the following horizons: $0-20,20-44,44-95$, and $95-150 \mathrm{~cm}$. Support soil characteristics data were determined using standard procedures (Klute, 1986). The soils were then classified as fine, loamy, mixed hyperthemic, and typic haplosalids.

Bulk densities were determined using the core method and the resultant bulk densities were $1.19,1.26$, 1.32 , and $1.37 \mathrm{Mgm}^{-3}$, respectively. Soil samples were collected from the four horizons, air dried, thoroughly mixed, crushed, and passed through a 2-mm sieve. Forty-eight columns, each $50 \mathrm{~cm}$ long, were assembled from PVC sections 10-cm long and $8.5 \mathrm{~cm}$ in inside diameter, and were held together with adhesive tape. Each column was closed firmly at the bottom end with a piece of cloth. The four samples were then packed uniformly in the same sequence as occured in the soil profile, so that each layer occupied about $10 \mathrm{~cm}$ of the column length. The soil was added in small aliquots, and the columns were dropped a known number of times over a vertical distance of $5 \mathrm{~cm}$ on a leveled support, to give bulk densities similar to field conditions.

The top layers $(0-10 \mathrm{~cm})$ of 32 columns were treated with peatmoss $(<2 \mathrm{~mm})$ and a cross-linked synthetic hydrogel polymer (Water Works, produced by Water Works America, Inc., Cleveland, $\mathrm{OH}$ ) amendments (16 columns each) before packing. Peatmoss was added at the rate of 45 tons per hectare (25 grams per column), whereas the recommended rate of the polymer ( 2 pounds per cubic yard) was applied, amounting to 0.6 grams per column. The last 16 columns were left untreated (control).

Saline well-water $(\mathrm{EC}=3,600 \mu \mathrm{S} / \mathrm{cm})$ and nonsaline tap water $(\mathrm{EC}=560 \mu \mathrm{S} / \mathrm{cm})$ were applied at two rates (R), 3 and $6 \mathrm{~mm} \mathrm{~d}^{-1}$, and two intervals (I), 5 and 10 days. The total amount of water actually applied on the day of irrigation was the product of the rate and the irrigation interval. Treatments were replicated twice and the soil columns were maintained in a vertical position and arranged randomly in an open but protected area. Water was applied gently over a glass rod to prevent soil puddling.

Mean daily temperatures of $26.6^{\circ} \mathrm{C}$, average daily humidity of $66.3 \%$, average daily wind speed $\left(\mathrm{U}_{2}\right)$ of $2.0 \mathrm{~m} / \mathrm{s}$ and Piche evaporation equivalent to $8.4 \mathrm{~mm} \mathrm{~d}^{-1}$ prevailed during the period of study.

Soil water evaporation was determined by daily weighing of each soil column. Gravimetric measurements of the soil water distribution were made at the end of the total irrigation periods (i.e., 35 and 40 days). At the given time, each of the appropriate columns was sectioned and the soil of each section was transferred to a weighing can to determine its moisture content. 


\section{WATER AND SALT DISTRIBUTION IN SALINE-SODIC SOIL}

\section{TABLE 1}

\begin{tabular}{|c|c|c|c|c|c|c|}
\hline \multirow{2}{*}{$\begin{array}{l}\text { Depth } \\
(\mathrm{cm})\end{array}$} & \multicolumn{3}{|c|}{ Particle-size distribution } & \multirow{2}{*}{$\begin{array}{l}\mathrm{pH} \text { of } \\
\text { Paste }\end{array}$} & \multirow{2}{*}{$\begin{array}{c}\mathrm{EC}_{\mathrm{e}} \\
(\mathrm{mS} / \mathrm{cm})\end{array}$} & \multirow{2}{*}{$\begin{array}{c}\mathrm{SAR}_{\mathrm{e}} \\
(\mathrm{meq} / \mathrm{L})^{0.5}\end{array}$} \\
\hline & Clay & Silt & Sand & & & \\
\hline 0 & 12.2 & 51.7 & 36.1 & 7.8 & 16.8 & 92.1 \\
\hline $20-44$ & 8.2 & 67.4 & 24.4 & 8 & 7.9 & 57.9 \\
\hline $44-95$ & 28.1 & 53 & 18.9 & 7.8 & 7.1 & 57.8 \\
\hline $95-150$ & 37.7 & 38.7 & 23.6 & 8.1 & 4.0 & 20.8 \\
\hline
\end{tabular}

After a soil sample was taken for moisture determination, the remaining soil of each section was air-dried, crushed, and saved for chemical analysis. Atomic absorption spectrophotometry was used for $\mathrm{Ca}$ and $\mathrm{Mg}$ determination, whereas $\mathrm{Na}$ was determined by flame photometry. The electrical conductivity (EC) was measured using a Jenway conductivity meter.

\section{Results and Discussion}

The results of the analysis of the soil samples collected from the profile showed that the successive layers were loam, sandy loam, and clay loam (Table 1). These results also revealed the problematic nature of the soils rendered saline and highly sodic by seawater intrusion into the ground aquifers due to over-pumping in the Batinah area (Abdel Rahman et al., 1993).

INTERMITTENT EVAPORATION: Figures 1, 2, and 3 show the cyclic cumulative evaporation (E) versus time relationships as affected by the soil amendment, water quality, and the interactions of the application rates and intervals, respectively. At the end of the 7th drying cycle, the cross-linked polymer (Water Works) reduced evaporation by 18.4 and $10.2 \%$ over the control and peatmoss, respectively (Figure 1). Peatmoss reduced evaporation by $9.1 \%$ over the control. Regression

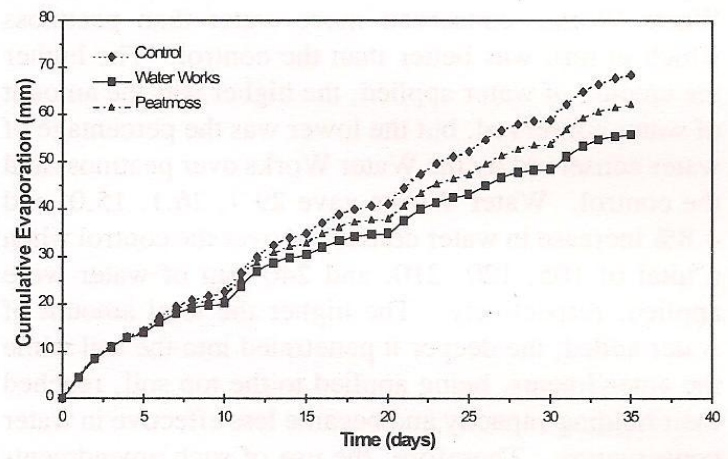

Figure 1. Effect of soil amendments on cumulative evaporation (average of all rates and intervals).

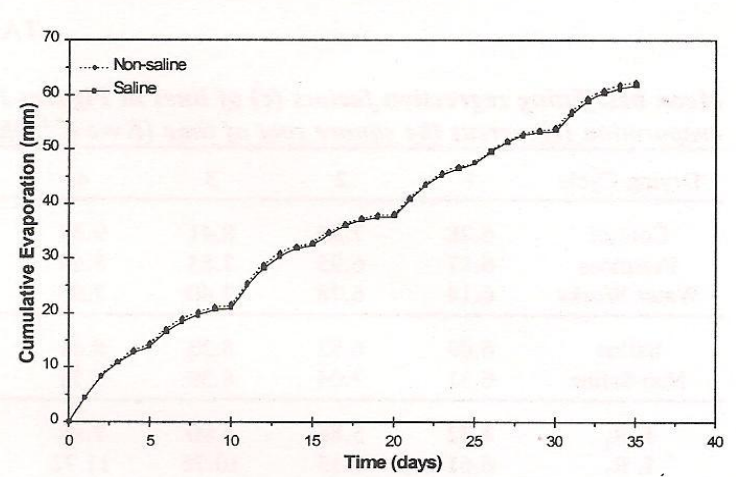

Figure 2. Effect of water quality on cumulative evaporation (average of treatments, rates, and intervals).

analysis showed that for each drying cycle, $\mathrm{E}$ was a linear function of the square root of time (Table 2), i.e., $\mathrm{E}=\mathrm{c} / \mathrm{t}$ as reported in previous studies (Abdel Rahman et al., 1996; Dahab et al., 1988). The values of $\mathrm{c}$ and hence $\mathrm{E}$ were the highest for control followed by peatmoss and Water Works. During the early cycles, the values of the cumulative evaporation constants were closer for all treatments. The differences in c values, and hence evaporation, between treatments became progressively greater with the drying cycle $(\mathrm{N})$, with the relationship $\mathrm{c}=\mathrm{a} \mathrm{N}+\mathrm{b}$ where $\mathrm{a}$ and $\mathrm{b}$ are empirical constants. The water quality had no profound effect on evaporation from the soil as illustrated in Figure 2. Similar behavior of the cyclic trend was obtained from all treatments irrigated with saline water $(3,600 \mu \mathrm{S} / \mathrm{cm})$ and non-saline water $(560 \mu \mathrm{S} / \mathrm{cm})$ with almost identical c values. Evaporation from columns irrigated with saline water was expected to be less due to the reduced vapor pressure caused by dissolved salts. This was not significant at this concentration. The slight variation could be attributed to the improved penetration of the saline water into the soil, hence marginally decreasing evaporation. Figure 3 shows the effect of irrigation

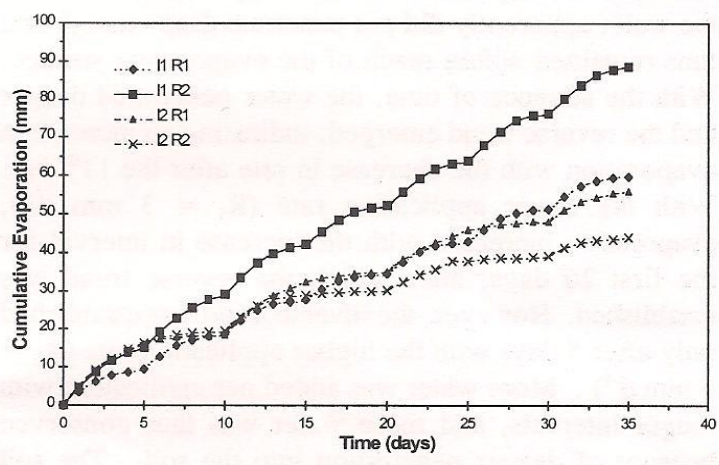

Figure 3. Effect of irrigation water frequency and water application rate on cumulative evaporation. 


\section{ABDEL RAHMAN AND IBRAHIM}

TABLE 2

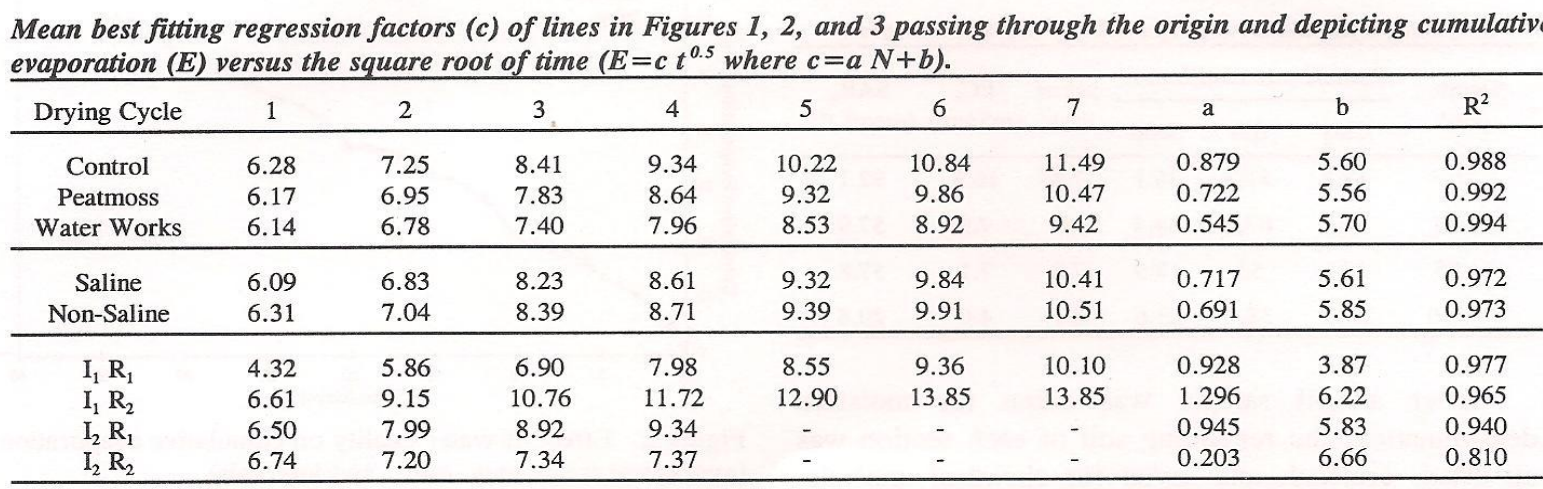

TABLE 3

Cumulative evaporation (E) and percentage of water conserved $(\% W C)$ at the end of $(N)$ drying cycles as affected by soil and amendment and irrigation interval and water application rate $(1 \times R) *$.

\begin{tabular}{|c|c|c|c|c|c|c|c|c|c|c|c|c|}
\hline & $\underset{(\mathrm{mm})}{\operatorname{I} \mathrm{X} R \mathrm{R}}$ & $\underset{(\mathrm{mm})}{E}$ & $\% \mathrm{WC}$ & IX R X N & $\begin{array}{c}E \\
(\mathrm{~mm})\end{array}$ & $\% \mathrm{WC}$ & $\begin{array}{l}\underset{(\mathrm{I} X \mathrm{R} \times)}{(\mathrm{mm})} \\
\end{array}$ & $\begin{array}{c}\mathrm{E} \\
(\mathrm{mm})\end{array}$ & $\% \mathrm{WC}$ & $\begin{array}{c}\text { I X R X N } \\
(\mathrm{mm})\end{array}$ & $\begin{array}{c}\mathrm{E} \\
(\mathrm{mm})\end{array}$ & $\% \mathrm{WC}$ \\
\hline Control & 105 & 65.7 & 37.4 & 210 & 96.9 & 53.9 & 120 & 65.3 & 45.6 & 240 & 49.6 & 79.3 \\
\hline Peatmoss & 105 & 59.8 & 43 & 210 & 88.8 & 57.7 & 120 & 57.5 & 52.1 & 240 & 45.8 & 80.9 \\
\hline
\end{tabular}

frequency and water application rates on cumulative evaporation averaged over all treatments and replicates. For the lower interval $\left(I_{1}=5\right.$ days), the higher water application rate $\left(\mathbb{R}_{2}=6 \mathrm{~mm} \mathrm{d^{-1 }}\right)$ resulted in more evaporation than the lower rate $\left(\mathrm{R}_{1}=3 \mathrm{~mm} \mathrm{~d}^{-1}\right)$ all the time. However, with the higher interval $\left(I_{2}=10\right.$ days), the $6 \mathrm{~mm} \mathrm{~d}^{-1}\left(\mathrm{R}_{2}\right)$ yielded more evaporation than the 3 $\mathrm{mm} \mathrm{d}^{-1}\left(\mathrm{R}_{1}\right)$ only for the first eleven days, after which a reverse trend emerged. The longer the interval the greater was the quantity of water applied per irrigation and made readily accessible for evaporation. At first, the water apparently did not penetrate deep enough and thus remained within reach of the evaporating surface. With the advance of time, the water penetrated deeper and the reverse trend emerged, indicating an increase in evaporation with the decrease in rate after the $11^{\text {th }}$ day. With the lower application rate $\left(\mathbb{R}_{1}=3 \mathrm{~mm} \mathrm{~d}^{-1}\right)$, evaporation increased with the increase in interval for the first 26 days, after which the reverse trend was established. However, the reverse trend was established only after 5 days with the higher application rate $\left(\mathbb{R}_{2}=\right.$ $6 \mathrm{~mm} \mathrm{~d}^{-1}$ ). More water was added per application with longer intervals, and more water was thus conserved because of deeper penetration into the soil. The soil developed more and more relatively deeper cracks that facilitated water penetration and hence reduced evaporation. It can thus be stated that evaporation increased with a decrease in irrigation interval after a threshold which was longer for the lower rate of water application; 26 days for $3 \mathrm{~mm} \mathrm{~d}^{-1}$ applications and 5 days for $6 \mathrm{~mm} \mathrm{~d}^{-1}$.

SOIL WATER DISTRIBUTION: Table 3 shows the cumulative evaporation at the end of the drying cycles, and the percentage of water conserved under different experimental conditions. The cross-linked polymer, Water Works, conserved more water than peatmoss which in turn was better than the control. The higher the amount of water applied, the higher was the amount of water conserved, but the lower was the percentage of water conserved by the Water Works over peatmoss and the control. Water Works gave 29.7, 26.1, 15.0, and $4.8 \%$ increase in water conserved over the control when a total of $105,120,210$, and $240 \mathrm{~mm}$ of water were applied, respectively. The higher the total amount of water added, the deeper it penetrated into the soil while the amendments, being applied to the top soil, reached their holding capacity and became less effective in water conservation. Therefore, the use of such amendments would only be of value in limited (deficit) irrigation. 


\section{WATER AND SALT DISTRIBUTION IN SALINE-SODIC SOIL}

The moisture content increased with depth, and the higher the total amount of water applied, the higher was the moisture conserved. Soil moisture distribution was governed by the amount of water conserved. Factors that reduced $\mathrm{E}$ caused more soil moisture conservation and consequently more soil moisture distribution. Table 4 shows the analysis of variance of the main effects on soil moisture distribution. The effects of the irrigation interval, rate, amendments, and their interactions were found to be highly significant, whereas the water quality made no significant difference. Water Works resulted in higher moisture retention, and hence higher water conservation. The higher the application rate and/or the irrigation interval, the higher was the soil-water retained, which significantly increased with depth. The amount of water applied per irrigation, however, seemed to have made the difference, rather than the total amount of water applied. Applying $60 \mathrm{~mm}$ per irrigation $\left(\mathrm{I}_{2} \mathrm{R}_{2}\right)$ significantly increased the moisture conserved in the profile. But applying $30 \mathrm{~mm}$ per irrigation either as $I_{1} R_{2}$ or $I_{2} R_{1}$ gáve no significant difference whether a total of $210 \mathrm{~mm}$ was applied in 7 irrigations with $I_{1} R_{2}$ or $120 \mathrm{~mm}$ was applied in 4 irrigations with $\mathbb{I}_{2} R_{1}$ (Table 5). This is in agreement with the previous findings that in cyclic irrigations, the amount of water applied per irrigation, rather than the cumulative amount, governs the soil-water content where soil dries up between irrigations.

ELECTRICAL CONDUCTIVITY REDISTRIBUTION: The amount of salt retained, as indicated by the $\mathrm{EC}_{1: 5}$, was ascribed to the amount of moisture conserved, increasing with depth (Table 6). Significant differences prevailed between the amendments within the different sections of the profile. At the top two layers, peatmosstreated columns leached salts more effectively than the untreated or Water Works-treated soil, which was the least effective. Peatmoss was significantly different than Water Works in leaching the top $20 \mathrm{~cm}$. No significant differences were detected between Water Works treated and untreated columns in these layers. In the third layer, peatmoss-treated soils were not significantly

TABLE 4

Soil moisture content as affected by soil conditioners, water quality, application rate and interval, and its distribution through the profile for different conditioners.

\begin{tabular}{|c|c|c|c|c|c|c|c|c|c|c|c|c|c|}
\hline \multirow{2}{*}{ Treatment } & \multicolumn{2}{|c|}{$\begin{array}{l}\text { Water Quality } \\
\qquad\left(\mu \mathrm{Scm}^{-1}\right)\end{array}$} & \multicolumn{3}{|c|}{$\begin{array}{l}\text { Application Rate } \\
\left(\mathrm{mm} \mathrm{d}^{-1}\right)\end{array}$} & \multicolumn{3}{|c|}{$\begin{array}{c}\text { Interval } \\
\text { (days) }\end{array}$} & \multicolumn{5}{|c|}{$\begin{array}{l}\text { Depth } \\
(\mathrm{cm})\end{array}$} \\
\hline & 560 & 3600 & 3 & 6 & L.S.D. & 5 & 10 & L.S.D. & 0 & 36452 & $20-30$ & $30-40$ & L.S.D. \\
\hline Control & $\stackrel{\text { A }}{19.7 b}$ & $\begin{array}{c}\mathrm{A} \\
21.8 \mathrm{~b}\end{array}$ & $\begin{array}{c}\mathrm{B} \\
16.7 \mathrm{c}\end{array}$ & $\begin{array}{c}\mathrm{A} \\
24.8 \mathrm{~b}\end{array}$ & 6 & $\begin{array}{c}\mathrm{B} \\
17.5 \mathrm{~b}\end{array}$ & $\begin{array}{c}\text { A } \\
24.0 \text { b }\end{array}$ & 6.1 & $\begin{array}{c}\mathrm{D} \\
9.0 \mathrm{c}\end{array}$ & $\begin{array}{c}\mathrm{C} \\
16.2 \mathrm{c}\end{array}$ & $\begin{array}{c}B \\
23.6 \mathrm{c}\end{array}$ & $\begin{array}{c}\mathrm{A} \\
34.1 \mathrm{~b}\end{array}$ & 6 \\
\hline Peatmoss & $\begin{array}{c}\text { A } \\
27.3 \mathrm{a}\end{array}$ & $\begin{array}{c}\mathrm{A} \\
27.4 \mathrm{a}, \mathrm{b}\end{array}$ & $\begin{array}{c}\text { B } \\
23.5 \mathrm{~b}\end{array}$ & $31.3 \mathrm{a}, \mathrm{b}$ & 6.9 & $\begin{array}{c}\text { B } \\
21.9 \mathrm{~b}\end{array}$ & $32.9 \mathrm{a}$ & 6.6 & $\begin{array}{c}\mathrm{D} \\
11.7 \mathrm{~b}\end{array}$ & $\begin{array}{c}\mathrm{C} \\
22.2 \mathrm{~b}\end{array}$ & $\begin{array}{c}\text { B } \\
32.4 \mathrm{~b}\end{array}$ & $\begin{array}{c}\text { A } \\
43.3 b\end{array}$ & 5.8 \\
\hline Water Works & $\begin{array}{c}\text { A } \\
34.4 \text { a }\end{array}$ & $\begin{array}{c}\text { A } \\
34.5 \text { a }\end{array}$ & $\begin{array}{c}\text { B } \\
29.5 \text { a }\end{array}$ & $39.3 \mathrm{a}$ & 8.6 & $\begin{array}{c}B \\
28.9 a\end{array}$ & $40.0 \mathrm{a}$ & 8.5 & $\begin{array}{c}D \\
15.0 \mathrm{a}\end{array}$ & $\begin{array}{c}\mathrm{C} \\
28.3 \mathrm{a}\end{array}$ & $\begin{array}{c}\text { B } \\
40.1 \mathrm{a}\end{array}$ & $\begin{array}{c}\text { A } \\
54.4 \text { a }\end{array}$ & 7.2 \\
\hline L.S.D. & 7.5 & 7.5 & 55 & 8.6 & & 6 & 8 & & 1 & 5.4 & 6.6 & 9.5 & \\
\hline
\end{tabular}

Figures followed by the same letters are not significant at the $5 \%$ level.

Capital letters for rows and small letters for columns.

TABLE 5

Electrical conductivity, sodium adsorption ratio, and soil moisture content as affected by the interactions of the application rates and intervals.

\begin{tabular}{|c|c|c|c|c|c|c|c|c|c|}
\hline & \multicolumn{3}{|c|}{$\mathrm{EC}_{1: 5}\left(\mu \mathrm{Scm}^{-1}\right)$} & \multicolumn{3}{|c|}{$\mathrm{SAR}_{\mathrm{e}}$} & \multicolumn{3}{|c|}{$\mathrm{MC} \%$} \\
\hline & $\mathbf{R}_{1}$ & $\mathrm{R}_{2}$ & L.S.D. & $\mathbf{R}_{1}$ & $\mathrm{R}_{2}$ & L.S.D. & $\mathbf{R}_{1}$ & $\mathrm{R}_{2}$ & L.S.D. \\
\hline $\mathrm{I}_{1}$ & $\frac{A}{2476 a}$ & $\begin{array}{c}\text { B } \\
1538 \text { a }\end{array}$ & 447 & $\begin{array}{c}\text { A } \\
49.8 \mathrm{a}\end{array}$ & $\begin{array}{c}\text { B } \\
39.1 \mathrm{a}\end{array}$ & 6.1 & $\begin{array}{c}\text { B } \\
19.6 \mathrm{~b}\end{array}$ & $\begin{array}{c}A \\
25.9 b\end{array}$ & 5.1 \\
\hline $\mathrm{I}_{2}$ & $\begin{array}{c}\text { A } \\
2229 \text { a }\end{array}$ & $\begin{array}{c}\text { B } \\
1294 \mathrm{a}\end{array}$ & 539 & $\begin{array}{c}\text { A } \\
49.9 \mathrm{a}\end{array}$ & $\begin{array}{c}\text { B } \\
34.6 \mathrm{a}\end{array}$ & 5.8 & $\begin{array}{c}B \\
26.9 \text { a }\end{array}$ & $\begin{array}{c}\text { A } \\
37.7 \mathrm{a}\end{array}$ & 6.7 \\
\hline L.S.D. & N.S. & N.S. & & N.S. & N.S. & & 4.7 & 7 & \\
\hline
\end{tabular}

Figures followed by the same letters are not significant at the $5 \%$ level.

Capital letters for rows and small letters for columns. 
ABDEL RAHMAN AND IBRAHIM

TABLE 6

Electrical conductivity of the $1: 5$ soil water extract as affected by soil conditioners, water quality, application rate and interval, and its distribution through the profile for different conditioners.

\begin{tabular}{|c|c|c|c|c|c|c|c|c|c|c|c|c|}
\hline \multirow{2}{*}{ Treatment } & \multicolumn{2}{|c|}{$\begin{array}{l}\text { Water Quality } \\
\qquad\left(\mu \mathrm{Scm}^{-1}\right)\end{array}$} & \multicolumn{3}{|c|}{$\begin{array}{l}\text { Application Rate } \\
\left(\mathrm{mm} \mathrm{d}^{-1}\right)\end{array}$} & \multicolumn{2}{|c|}{$\begin{array}{c}\text { Interval } \\
\text { (days) }\end{array}$} & \multicolumn{5}{|c|}{$\begin{array}{l}\text { Depth } \\
(\mathrm{cm})\end{array}$} \\
\hline & 560 & 3600 & 3 & 6 & L.S.D. & 5 & 10 & 0 & 36452 & $20-30$ & $30-40$ & L.S.D. \\
\hline Control & $\frac{A}{1669 a}$ & $\begin{array}{c}A \\
1823 \mathrm{a}\end{array}$ & $\begin{array}{c}\text { A } \\
1949 a\end{array}$ & $\begin{array}{c}\mathrm{A} \\
1542 \mathrm{a}\end{array}$ & N.S. & $\begin{array}{c}\text { A } \\
1872 a\end{array}$ & $\frac{A}{1620 \mathrm{a}}$ & $\frac{B}{1275 a, b}$ & $\begin{array}{c}\text { B } \\
1394 \mathrm{a}, \mathrm{b}\end{array}$ & $\begin{array}{c}\text { B } \\
1178 \mathrm{~b}\end{array}$ & $\begin{array}{c}\text { A } \\
3136 \mathrm{a}\end{array}$ & 655 \\
\hline Peatmoss & $\frac{\mathrm{A}}{1651 \mathrm{a}}$ & $\begin{array}{c}\text { A } \\
2070 \text { a }\end{array}$ & $\begin{array}{c}A \\
2454 a\end{array}$ & $\begin{array}{c}\text { B } \\
1267 \mathrm{a}\end{array}$ & 719 & $\begin{array}{c}\text { A } \\
1996 \mathrm{a}\end{array}$ & $\begin{array}{c}\text { A } \\
1724 \text { a }\end{array}$ & $\begin{array}{c}\text { B } \\
1036 b\end{array}$ & $\begin{array}{c}\text { B } \\
1294 \text { b }\end{array}$ & $\frac{B}{1472 \mathrm{a}, \mathrm{b}}$ & $\begin{array}{c}\text { A } \\
3640 \mathrm{a}\end{array}$ & 826 \\
\hline Water Works & $\begin{array}{c}\mathrm{A} \\
1957 \mathrm{a}\end{array}$ & $\begin{array}{c}\text { A } \\
2139 a\end{array}$ & $\begin{array}{c}\text { A } \\
2657 \text { a }\end{array}$ & $\begin{array}{c}B \\
1439 a\end{array}$ & 471 & $\begin{array}{c}\text { A } \\
2154 \mathrm{a}\end{array}$ & $\begin{array}{c}\text { A } \\
1942 \text { a }\end{array}$ & $\begin{array}{c}\mathrm{B} \\
1580 \mathrm{a}\end{array}$ & $\begin{array}{c}\mathrm{B} \\
1822 \mathrm{a}\end{array}$ & $\begin{array}{c}\text { B } \\
1959 \mathrm{a}\end{array}$ & $\begin{array}{c}\mathrm{A} \\
2830 \mathrm{a}\end{array}$ & 734 \\
\hline L.S.D. & N.S. & N.S. & N.S. & N.S. & & N.S. & N.S. & 416 & 419 & 531 & N.S. & \\
\hline
\end{tabular}

Figures followed by the same letters are not significant at the $5 \%$ level.

Capital letters for rows and small letters for columns.

TABLE 7

Sodium adsorption ratio of the saturation extract as affected by soil conditioners, water quality, application rate and interval, and its distribution through the profile for different conditioners.

\begin{tabular}{|c|c|c|c|c|c|c|c|c|c|c|c|c|}
\hline \multirow[t]{2}{*}{ Treatment } & \multicolumn{2}{|c|}{$\begin{array}{l}\text { Water Quality } \\
\qquad\left(\mu \mathrm{Scm}^{-1}\right)\end{array}$} & \multicolumn{3}{|c|}{$\begin{array}{l}\text { Application Rate } \\
\left(\mathrm{mm} \mathrm{d}^{-1}\right)\end{array}$} & \multicolumn{2}{|c|}{$\begin{array}{c}\text { Interval } \\
\text { (days) }\end{array}$} & \multicolumn{5}{|c|}{$\begin{array}{c}\text { Depth } \\
(\mathrm{cm})\end{array}$} \\
\hline & 560 & 3600 & 3 & 6 & L.S.D. & 5 & 10 & 0 & 36452 & $20-30$ & $30-40$ & L.S.D. \\
\hline Control & $\begin{array}{c}\mathrm{A} \\
44.0 \mathrm{a}\end{array}$ & $\begin{array}{c}\text { A } \\
46.4 \mathrm{a}\end{array}$ & $\begin{array}{c}\mathrm{A} \\
51.4 \mathrm{a}\end{array}$ & $\begin{array}{c}\mathrm{A} \\
39.0 \mathrm{a}\end{array}$ & 7.6 & $\begin{array}{c}\text { A } \\
46.0 \text { a }\end{array}$ & $\begin{array}{c}\text { A } \\
44.4 \mathrm{a}\end{array}$ & $\begin{array}{c}\mathrm{D} \\
23.8 \mathrm{a}\end{array}$ & $\begin{array}{c}C \\
40.9 a\end{array}$ & $\begin{array}{c}\text { B } \\
55.2 \mathrm{a}\end{array}$ & $\begin{array}{c}A \\
60.9 \mathrm{a}\end{array}$ & 5.5 \\
\hline Peatmoss & $\begin{array}{c}\text { A } \\
42.6 \mathrm{a}\end{array}$ & $\begin{array}{c}\text { A } \\
45.2 \mathrm{a}\end{array}$ & $\begin{array}{c}\mathrm{A} \\
51.1 \mathrm{a}\end{array}$ & $\begin{array}{c}\text { B } \\
36.7 \mathrm{a}\end{array}$ & 7.4 & $\begin{array}{c}\text { A } \\
45.3 \mathrm{a}\end{array}$ & $\begin{array}{c}\mathrm{A} \\
42.5 \mathrm{a}\end{array}$ & $\begin{array}{c}\mathrm{D} \\
23.4 \mathrm{~b}\end{array}$ & $\begin{array}{c}C \\
40.1 \mathrm{a}\end{array}$ & $\begin{array}{c}\mathrm{B} \\
52.2 \mathrm{a}\end{array}$ & $\begin{array}{c}\text { A } \\
59.8 \text { a }\end{array}$ & 6.2 \\
\hline Water Works & $\begin{array}{c}\mathrm{A} \\
39.3 \mathrm{a}\end{array}$ & $\begin{array}{c}\text { A } \\
42.6 \mathrm{a}\end{array}$ & $\begin{array}{c}\text { A } \\
47.1 \mathrm{a}\end{array}$ & $\begin{array}{c}\mathrm{B} \\
34.8 \mathrm{a}\end{array}$ & 7.1 & $42.2 \mathrm{a}$ & $\begin{array}{c}\mathrm{A} \\
39.7 \mathrm{a}\end{array}$ & $\begin{array}{c}D \\
21.7 \mathrm{a}\end{array}$ & $\begin{array}{c}\mathrm{C} \\
37.0 \mathrm{a}\end{array}$ & $\begin{array}{c}B \\
50.6 \text { a }\end{array}$ & $\begin{array}{c}\mathrm{A} \\
54.6 \mathrm{a}\end{array}$ & 6 \\
\hline L.S.D. & N.S. & N.S. & N.S. & N.S. & & N.S. & N.S. & N.S. & N.S. & N.S. & 2.8 & \\
\hline
\end{tabular}

Figures followed by the same letters are not significant at the $5 \%$ level.

Capital letters for rows and small letters for columns.

different than either of the Water Works-treated or the untreated soils which were significantly different than each other. Evaporation from the soil surface brought back some of the salts from the third layer to the top two layers in untreated soils, whereas salts were leached down in peatmoss-treated soils.

Water quality had no significant effect on the amount of salts retained and the increase in salt deposit by the $3600 \mu \mathrm{Scm}^{-1}$ water was not enough to bring about any significant changes, but the better quality water $\left(560 \mu \mathrm{Scm}^{-1}\right.$ ) seemed to be more effective in salt leaching with peatmoss. Irrigation interval effect was not significant either, but in the top layer the 5-day interval caused more salts to be retained. This was attributed to the total amount or water added and the evaporation losses. The effects of the application rates, on the other hand, were significant in salt leaching (higher rates inducing more leaching). Thus, the total quantity of water applied seemed to have the significant effect (Table 5). Applying a total of $240 \mathrm{~mm}$ of water $\left(\begin{array}{ll}I_{2} & R_{2}\end{array}\right)$ significantly reduced the amounts of salts retained compared to applying $210 \mathrm{~mm}\left(I_{1} R_{2}\right)$ or lower quantities. Even though $30 \mathrm{~mm}$ of water were applied per irrigation in both the $I_{1} R_{2}$ and $I_{2} R_{1}$ treatments, applying a total of $210 \mathrm{~mm}$ in 7 irrigations of $I_{1} R_{2}$ significantly induced leaching than the total quantity of $120 \mathrm{~mm}$ applied in 4 irrigations of the $I_{2} R_{1}$ treatments.

SODIUM ADSORPTION RATIO REDISTRIBUTION: The behavior of the SAR redistribution was somewhat similar to that of the EC redistribution since SAR significantly increased with depth (Table 7). Water Works- and peatmoss-treated soils were not significantly any different than the untreated soils. There was, however, a trend of a slight increase in the SAR retained in the order of control followed by peatmoss 


\section{WATER AND SALT DISTRIBUTION IN SALINE-SODIC SOIL}

and Water Works which was only significant in the bottom layer. This could be explained by the mobility of sodium ( $\mathrm{Na}$ ) in the process of redistribution with evaporation which was in the same order. Even though the differences were not significant, Water Works showed less SAR retention and hence more leaching associated with moisture conservation and evaporation reduction. Similar to the $\mathrm{EC}$ redistribution, the cumulative amount of water applied made the differences, rather than the quantity of water applied at a time.

\section{Conclusion}

Cross-linked polymers proved to be efficient in soil moisture retention and water conservation. Peatmoss, however, was significantly effective in leaching salts, down the soil profile, compared to the copolymer that slightly reduced the SAR values. Moderately saline water did not enhance leaching, possibly because the level of salinity was ineffective and that the predominant salt in the irrigation water was sodium. Salt leaching was improved as time progressed and the total amount of water applied increased. The soil moisture conserved, however, was dependent on the amount of water applied per irrigation.

\section{References}

Abdel Rahman, H.A., A. Lepiece, and V. Macalinga. 1993. Some physical and chemical characteristics of the Batinah soils. Communications in Soil Science and Plant Analysis 24(17\&18):2293-2305.

Abdel Rahman, H.A. and I.M. Abdel Majid. 1993. Water Conservation in Oman. Water International 18:95-102.
Abdel Rahman, H.A., M.A. Dahab, and M.A. Mustafa. 1996. Impact of soil amendments on intermittent evaporation, moisture distribution and salt redistribution. Soil Science 161(11):793-802.

Al-Omran, A.M., M.A. Mustafa, and A.A. Shalaby. 1987. Intermittent evaporation from soil columns as affected by a gelforming conditioner. Soil Science Society of America Journal 51:1593-1599.

Andrian, D.C., P.E. Pratt, and S.E. Bishop. 1971. Nitrate and salt in soils and groundwaters from land disposal of dairy manure. Soil Science Society of America Journal 35:759-762.

Carrow, R.N., R.C. Sherman, and J.R. Watson. 1990. Turfgrass. In: Irrigation of Agricultural Crops, B.A. Stewart and D.R. Nielsen (Editors), 889-919. Agronomy Monograph 30, ASA, CSSA, and SSSA, Madison, WI.

Dahab, M.H., M.A. Mustafa, and H.A. Abdel Rahman. 1988. Intermittent evaporation, moisture distribution, and salt redistribution through saline-sodic clay soil as affected by irrigation frequency and quantity. Soil Science 146(3):168175.

Hemyari, P. and D.L. Nofziger. 1981. Super slurper effects on crust strength, water retention and water infiltration of soils. Soil Science Society of America Journal 45:799-801.

Johnson, M.S. 1984. Effect of soluble salts on water absorption by gel-forming soil conditioners. Science, Food and Agriculture 35:1063-1066.

Keller, R.J., and J.F. Alfaro. 1966. Effect of water application rate on leaching. Soil Science 102:107-115.

Klute, A. (Editor). 1986. Methods of Soil Analysis (2 ${ }^{\text {nd }}$ Edition). American Society of Agronomy, Madison, WI.

Oster, J.D., L.S. Willardson, and G.J. Hoffman. 1972. Sprinkling and ponding techniques for reclaiming saline soils. Transactions of the ASAE 15:1115-1117.

Tayel, M.Y. and O.A. El-Hady. 1981. Super gel as a soil conditioner: I. Its effect on some soil-water relations. Acta Hortica 119:247-256.

Tisdall, J.M. and J.M. Oades. 1982. Organic matter and waterstable aggregates in soils. Journal of Soil Science 33:141-163. 